\title{
MOISTURE RELEASE OF TROPICAL PEAT SOILS AS DECREASING WATER TABLE
}

\author{
Ahmad Kurnain \\ Department of Soil, Faculty of Agriculture, University of Lambung Mangkurat \\ Jalan Jenderal A. Yani km 36 Banjarbaru 70714 \\ Corresponding author: akurnain@unlam.ac.id
}

\begin{abstract}
Hydro-physics of peat soils varied with their peat decomposition degree. One of the important hydro-physics is ability of the peat soil to release water as decreasing water table. Potential of water availabilty to crop growth is evidently related to this behaviour. The present study was conducted to understand modes of moisture release of peat soils as decreasing water table. Water tables were simulated using a hanging column method. The water table was arranged at levels of $0,10,20,30,50$, and $100 \mathrm{~cm}$ below peat column surfaces. Potential of moisture release or in oppositely potential of moisture retention could be modelled with the 3 parameter equation. Highly decomposed peat characterized by higher bulk density and lower total porosity stored less water but retained more water.
\end{abstract}

Key words: available water, bulk density, peat soil, porosity.

\section{INTRODUCTION}

Characteristics of peat soil is different from the mineral soil. The difference is related to their formation process and parent materials. Due to their different parent materials the peat soil forms weaker and looser aggregates than the mineral soil. As a result the peat soil at a certain volume has much lower weight and higher total porosity than the mineral soil. The peat soil is substantially to retain higher amounts of water. Water holding capacities of tropical peat soils ranged between $200-3000 \%$ by weight base or $50-90 \%$ by volume base (Andriesse 1988; Kurnain 2005; Kurnain et al. 2006). The water holding capacity was dependent on its decomposition degree (Kurnain et al. 2006; Gnatowski et al. 2010; Kechavarzi et al. 2010). Peat soils collected on the natutral peat forest of Sebangau
Central Kalimantan contained more water than those collected on developed peatlands (Kurnain et al. 2002). This implies that fibric peat stores more water than sapric peat.

However the peat soil stores more water. only a few fraction of the water is available for plant growth. so called readily available water. Most of the remaining is gravitation water and strongly retained water. Lambert (1995) reported that peat samples from Pontianak West Kalimantan contained $17 \%$ volume of available water. even though their maximum water content reaching $88 \%$ volume.

Most agricutural practices in fields showed that water management is essential to the use of peatlands. Water drainage must be such that the depth of the groundwateris able to optimize the ability of peat to provide water for crops. Potential water supply for the needs of crops according to the depth of the groundwater level needs to be studied and described dynamically. It will be important for a drainage strategy in order to attempt reclamation of peatlands for agriculture.

\section{MATERIALS AND METHOD}

The research was conducted in laboratory scale experiments. Peat samples was collected in Gambut Sub District Banjar District. Banjang Sub District and Pulau Damar area of Hulu Sungai Utara in South Kalimantan. The sample was collected using a peat column made from PVC pipe with diameter and height of 10 and $60 \mathrm{~cm}$ respectively. The peat column sampler was inserted gently into the ground up to $50 \mathrm{~cm}$ in depth. and then the column containing peat was slowly lifted. The number of peat columns was 18 units in which 6 units for each site. During transport and before the study. both sides of the peat column were closed with PVC cover to avoid damage and loss of moisture. 


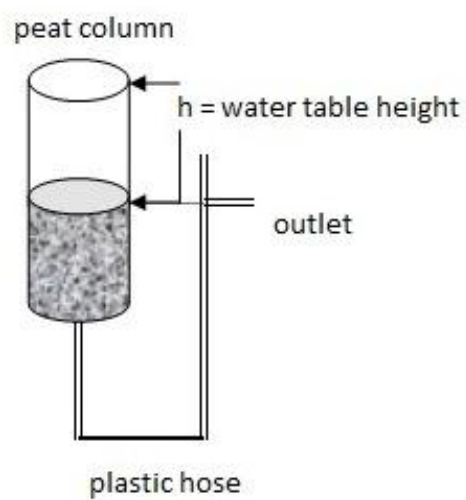

Figure 1 Hanging peat column

Setting the water tabel was simulated with a hanging column technique (Figure 1). At the beginning all the peat columns were water saturated by positioning the tip of a plastic hose at position $0 \mathrm{~cm}$ of the peat column surface. One week after water saturation. groundwater levels were set at a height of 0.10 .20 .30 .50 . and $100 \mathrm{~cm}$ below the surface of the peat column. One month after the equilibrium time. each peat column was cut every $5 \mathrm{~cm}$ in depth. Each peat cut on both sides was covered with plastic and sealed with wax for further determination of moisture content. bulk density. specific density. total porosity. and fiber content. All parameters were measured by the procdures stated in Kurnain (2005).

Potential of moisture release due to changes in groundwater levels was modeled with an equation that has been developed by Kurnain et al. (2002, 2003, 2006). The equation consists of two types those are 2 paremeters and 3 parameters of the equation. as the following:

The two parameters equation of moisture release

$$
\mathrm{V}_{\mathrm{wr}}=\mathrm{V}_{\max } \cdot \mathrm{e}^{-\mathrm{k}} \mathrm{wr}+\left(1+\mathrm{V}_{\max }\right) \cdot \mathrm{e}^{-\mathrm{k}} \mathrm{wr} r^{\mathrm{h}}
$$

in which $V_{w r}$ is volume of moisture release (\%vol). $V_{\max }$ volume of maximum moisture release $(\% \mathrm{vol}) . \mathrm{k}_{\mathrm{wr}}$ rate constant of moisture release $\left(\mathrm{cm}^{-1}\right)$ and $\mathrm{h}$ is water table height $(\mathrm{cm})$.

The three parameters equation of moisture release

$$
\begin{aligned}
V_{w r}=V_{\max } & \cdot e^{-k} w r+\left(1+V_{\max }\right) \cdot e^{-k} w r^{h} \\
& +V_{s}
\end{aligned}
$$

in which $\mathrm{V}_{\mathrm{s}}$ is volume of solids (\%vol). and others are the same as described above.

Calibration of the equation with obtained data was run by minimizing the sum of square difference. The calibration was aided with the Excel program using Solver. Efficiency of the equation and coefficient of determination were also calculated to compare the two equations tested.

\section{RESULTS AND DISCUSSION}

Amounts of moisture released due to decreasing water level might be described by the 2 and 3 parameters equation of potential moisture release. Calibration of the equation with obtained data provided different values of $V_{\max }$ and $k_{w r}$ parameters for both the equations tested (Table 1).

\begin{tabular}{|c|c|c|c|c|c|c|}
\hline \multirow{2}{*}{ Parameter/Statistics } & \multicolumn{2}{|l|}{ Gambut } & \multicolumn{2}{|l|}{ Banjang } & \multicolumn{2}{|c|}{ Pulau Damar } \\
\hline & $0-5 \mathrm{~cm}$ & $5-10 \mathrm{~cm}$ & $0-5 \mathrm{~cm}$ & $5-10 \mathrm{~cm}$ & $0-5 \mathrm{~cm}$ & $5-10 \mathrm{~cm}$ \\
\hline \multicolumn{7}{|l|}{2 parameters } \\
\hline $\mathrm{V}_{\max }$ & 50.94 & 35.95 & 42.80 & 29.12 & 35.69 & 37.05 \\
\hline $\mathrm{k}_{\mathrm{wr}}$ & 0.06 & 0.03 & 0.04 & 0.03 & 0.03 & 0.03 \\
\hline Eficiency & 0.80 & 0.96 & 0.63 & 0.24 & 0.87 & 0.87 \\
\hline $\mathrm{R}^{2}$ & 0.80 & 0.97 & 0.74 & 0.54 & 0.96 & 0.88 \\
\hline
\end{tabular}

Table 1. Parameters and statistics of the 2 and 3 parameters equation of moisture release due to changes in water table levels of peat columns 


\begin{tabular}{lllllll}
\hline 3 parameters & \multicolumn{7}{l}{} \\
\hline $\mathrm{V}_{\max }$ & 47.85 & 32.18 & 32.85 & 22.88 & 19.72 & 19.69 \\
\hline $\mathrm{K}_{\mathrm{wr}}$ & 0.06 & 0.06 & 0.03 & 0.02 & 0.03 & 0.04 \\
\hline $\mathrm{V}_{\mathrm{s}}$ & 11.84 & 10.49 & 20.22 & 17.17 & 26.85 & 22.40 \\
\hline Eficiency & 0.77 & 0.99 & 0.68 & 0.52 & 0.66 & 0.78 \\
\hline $\mathrm{R}^{2}$ & 0.77 & 0.99 & 0.68 & 0.52 & 0.66 & 0.78 \\
\hline
\end{tabular}

The maximum volume of moisture released $\left(\mathrm{V}_{\max }\right)$ as a result of changes in groundwater levels of peat columns from three sites was varied. The $V_{\max }$ value of the Gambut peat column was higher than that of the Banjang and Pulau Damar peat columns. This difference might be related to variation of bulk density and total porosity of the peat soils. Although the correlation between $\mathrm{V}_{\max }$ with bulk density and total porosity was not significant (Figure 2 and 3), there was a trend that the higher $\mathrm{V}_{\max }$ value corresponded with decreased bulk density and increased total porosity of the peat soils.

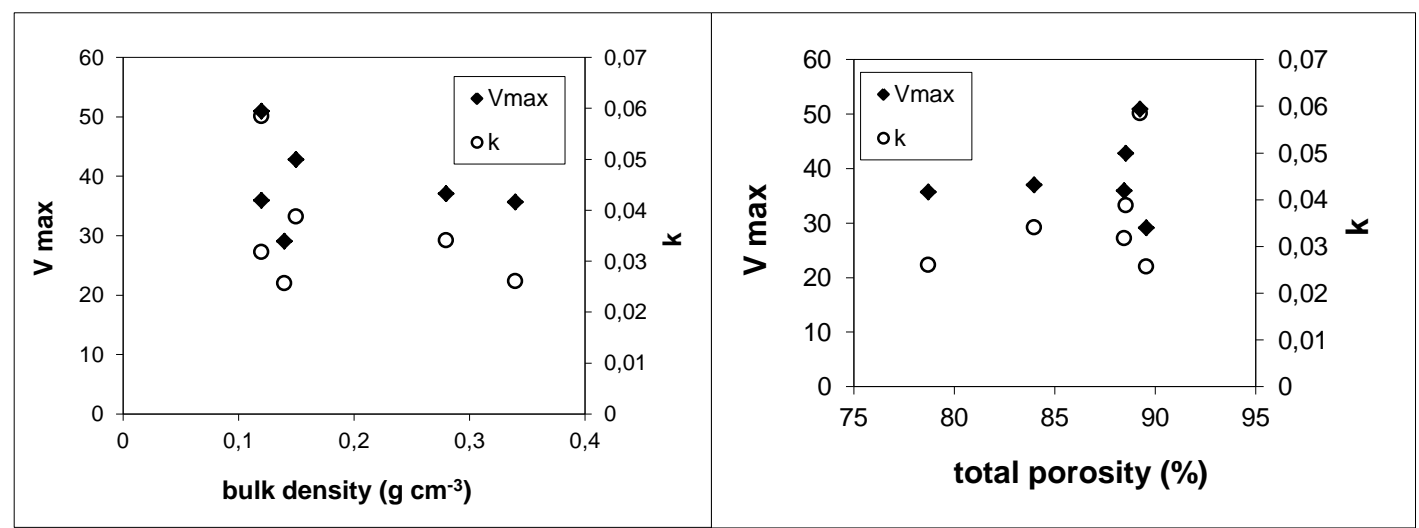

Figure 2. Correlation between parameters of the two parameters equation and bulk density and total porosity of the peat soil due to change in water table levels

Rate constant of moisture release $\left(\mathrm{k}_{\mathrm{wr}}\right)$ of both equations tested varied between 0:02 to 0:06 (0:04 in average). As with the $\mathrm{V}_{\max }$ value. Variation of $k$ value could also be explained by differences in bulk density total porosity of the peat soil. Mode of the $k$ value is similar to the $\mathrm{V}_{\max }$ value.



Figure 3. Correlation between parameters of the three parameters equation and bulk density and total porosity of the peat soil due to change in water table levels 
The peat soil with a higher bulk density and lower total porosity and therefore higher decomposition degree such as the peat columns of Banjang and Pulau Damar, signifies more densed and compacted and contains more micro-sized pore space. Micro pores will retain moisture more strongly, and consequenty the maximum volume and rate of moisture released due to reduced water levels become lower.

Many studies have revealed that peat soils with higher bulk density store moisture less than those with lower bulk density (Kurnain et al. 2002; Gnatowski et al. 2010). In agricultural practices, compaction of peat due to drained cropped peatlands causes changes in the peat structure, in particuar, bulk density and void ratio (Camporese et al. 2006). The peat soil with higher bulk density is composed of fine fibres resulting in more compacted structure, and consequently pore spaces are filled with less water (Gnatowski et al. 2010). In other words the peat soil with higher bulk density has typically lower total porosity (Gnatowski et al. 2010; Kurnain et al., 2002). Therefore the moisture storage capacity of peat soils is also determined by their porosity. The higher the total porosity is the more the amount of moisture stored in peat soils.

The moisture storage capacity of peat soils was not the same as the ability of peat soils to retain moisture. The moisture retaining capacity relates to ability of peat soils to retain moisture against suction forces working in the soil, including root suction and decreased water level. Simulation of decreased water level implied that peat soils with higher decomposition degree released moisture with less and more slowly (Blodau and Moore 2002). This means that the ability to retain moisture is stronger.

In practices, it could be recognized that less decomposed peat soils store more moisture during the rainy season, but hold less moisture during the dry season that is usually followed by a drop-down of groundwater level. The reverse is true for more decomposed peat soils. This water character will certainly have implications for potential of water availability for plant growth.

\section{CONCLUSION}

Potential of moisture release and retention of peat soils was better modeled by the three parameters equation than the two parameters equation. Simulation of decreased water level could be developed towards further research in the form of drainage system simulation on a small plot with a variation of the patterns of wet - dry condition or shallow - deep drainage systems.

\section{ACKNOWLEDGEMENTS}

The author would like to thank DGHE of Ministry of National Education for funding the present study. Any comments of this article will be appreciate greatly.

\section{REFERENCES}

Andriesse, J.P. 1988. Nature and Management of Tropical Peat Soils. FAO Soil Bulletin 59. Rome. Italy. $165 p$.

Blodau, C., and T.R. Moore. 2002. Macroporosity affects water movement and pore water sampling in peat soils. Soil Science, 167(2): 98-109.

Camporese, M., S. Ferraris, M. Putti, P. Salandin, and P. Teatini. 2006. Hydrological modeling in swelling/shrinking peat soils. Water Resources Research, 42: W06420, doi:10.1029/2005WR004495.

Gnatowski, T., J. Szatylowicz, T. Brandyk, and C. Kechavarzi. 2010. Hydraulic properties of fen peat soils in Poland. Geoderma, 154(3-4): 188 195.

Kechavarzi, C., Q. Dawson, and P.B. LeedsHarrison. 2010. Physical properties of low-lying agricultural peat soils in England. Geoderma, 154(3-4): 196202.

Kurnain, A. 2005. Dampak kegiatan pertanian dan kebakaran atas watak gambut ombrogen. Disertasi. Universitas Gadjah Mada. Yogyakarta.

Kurnain, A.. T. Notohadikusumo, B. Radjagukguk, and Sri Hastuti. 2002. The state of decomposition of tropical peat soil under cultivated and fire-damaged peatland. In: J. Rieley and S. Page (eds). Jakarta Symposium Proceedings on Peatlands for People. Natural Resources Function and 
Ahmad Kurnain: Moisture release of tropical peat soils as decreasing water table

Sustainable Management. p: 168178.

Kurnain, A.. T. Notohadikusumo, B. Radjagukguk, and Sri Hastuti. 2003. Impact of development and cultivation on hydro-physical properties of tropical peat soils. In: M. Osaki et al (eds). Proceedings of the International Symposium on Land Management and Biodiversity in Southeast Asia. p: 227-232.
Kurnain, A.. T. Notohadikusumo, B Radjagukguk, and Sri Hastuti. 2006. Impact of development and cultivation on hydro-physical properties of tropical peat soils. Tropics 15(4): 383-389.

Lambert. K. $1995 . \quad$ Physico-chemical characterisation of lowland tropical peat soil. PhD Thesis. RUG. Gent. Belgium. 161p. 